DOI:10.17951/h.2015.59.2.33

\begin{tabular}{lcc}
\hline \multicolumn{3}{c}{ A N N A L E S } \\
UNIVERSITATIS & MARIAE CURIE-SKŁODOWSKA \\
LUBLIN - POLONIA & \\
VOL. XLIX, 2 & SECTIOH H \\
\hline
\end{tabular}

Uniwersytet Marii Curie-Skłodowskiej w Lublinie, Zakład Ubezpieczeń

TERESA HANNA BEDNARCZYK

e-mail: teresa.bednarczyk@umcs.lublin.pl

\title{
Wyzwania demograficzne dla systemów emerytalnych w Unii Europejskiej
}

Demographic challenges for pension systems in the European Union

Słowa kluczowe: starzenie się społeczeństwa, niskie stopy zastąpienia, reformy emerytalne

Keywords: population ageing, low replacement rates, pension reforms

Wstęp

Jedną z kluczowych cech obecnych czasów jest problem starzejącego się społeczeństwa. Problem ten ma zasięg globalny, jednak najmocniej dotyka Europę. Proces starzenia demograficznego stanowi bezpośredni efekt wydłużania się przeciętnego trwania życia i spadku dzietności ogółem poniżej poziomu zastąpienia. Prognozowany spadek liczby osób w wieku najwyższej aktywności (20-59 lat) oraz rosnący odsetek emerytów - to zjawiska, które mają negatywny wpływ na potencjał wzrostu gospodarczego oraz na stabilność finansów publicznych, a zwłaszcza finansów emerytalnych. Systemy emerytalne oparte na solidarności międzypokoleniowej, przy spadających dochodach składkowych i rosnących wydatkach emerytalnych, nie będą w stanie zagwarantować adekwatnych emerytur. Jest to ogromne wyzwanie dla wszystkich krajów członkowskich Unii Europejskiej.

Głównym celem artykułu jest analiza skali zjawiska starzenia się społeczeństwa w krajach Unii Europejskiej, a także sposobów przezwyciężania problemów emerytalnych z tym związanych. Szczególna uwaga zostanie zwrócona na dhugofalowy plan modernizacji polityki emerytalnej na szczeblu Unii Europejskiej, który jest przejawem realizacji metody otwartej koordynacji systemów emerytalnych. 


\section{Systemy emerytalne w Unii Europejskiej i ich modelowe ujęcie}

Systemy emerytalne w państwach Unii Europejskiej są dość zróżnicowane, co jest rezultatem rozwoju historycznego oraz samodzielnie kształtowanej polityki emerytalnej. Składają się one z kilku warstw (zwanych filarami): publicznej, zakładowej i prywatnej. We wszystkich krajach publiczne systemy emerytalne odgrywają rolę najważniejszą. Wyróżnia się trzy podstawowe modele publicznych ubezpieczeń emerytalnych. Są to: model ubezpieczeniowy, zwany modelem Bismarcka, model zabezpieczenia społecznego Beveridge'a oraz model obywatelski, zwany też zaopatrzeniowym lub skandynawskim. Wszystkie rozwiązania modelowe opierają się na repartycyjnym mechanizmie finansowania (ang. pay-as-you-go), czyli solidarności międzypokoleniowej, co oznacza, że świadczenia emerytalne pokolenia emerytów są finansowane składkami (lub podatkami) pokolenia aktualnie pracującego.

W modelu ubezpieczeniowym podstawą do wypłaty pracownikom emerytur publicznych jest wcześniejsze opłacanie przez nich składek ubezpieczeniowych, które są obowiązkowe. Osoby prowadzące działalność gospodarczą mogą dobrowolnie przystępować do systemu. Emerytury z publicznego systemu ubezpieczeniowego są powiązane z dochodami pracowników (tzw. zasada ekwiwalentności) i mają za zadanie zastąpienie ich $\mathrm{w}$ okresie poprodukcyjnym, jednak na poziomie niskim lub średnim. Pracownicze programy emerytalne oraz inne indywidualne zabezpieczenia emerytalne mają w tym modelu znaczenie uzupełniające i dodatkowe.

W modelu Beveridge'a podstawowa emerytura państwowa (tzw. renta starcza) $\mathrm{z}$ ubezpieczenia społecznego jest wypłacana w jednolitej kwocie dla wszystkich, którzy osiągnęli wiek emerytalny oraz zaprzestali pracy zawodowej. Jej głównym celem jest zapobieganie ubóstwu wszystkich grup społecznych w okresie starości, a szczególnie grup narażonych na ryzyko biedy. Uzupełnieniem niskich emerytur podstawowych są systemy pracownicze, które rozwinęły się nie tylko w sektorze prywatnym, ale i w publicznym, oraz indywidualne plany emerytalne.

Model obywatelski wyróżnia się zaopatrzeniowym charakterem. Cechuje go finansowanie świadczeń z podatków ogólnych. Prawo do emerytury podstawowej uzależnia się od faktu zamieszkiwania w danym kraju (statusu rezydenta). Świadczenia emerytalne nie muszą być uzależnione od długości okresu uprzedniej pracy. W modelu tym, podobnie jak w modelu Beveridge'a, relatywnie niskie emerytury obywatelskie są uzupełniane poprzez dobrowolne pracownicze programy emerytalne, działające na zasadach rynkowych, oraz dobrowolne, indywidualne plany emerytalne.

Jednoznaczne przyporządkowanie systemu emerytalnego danego kraju do konkretnego modelu jest dość trudne, ponieważ wypracowane rozwiązania nie mają charakteru stałego. Ewoluują w kierunku dostosowywania do zmieniających się warunków gospodarczych i społecznych, a także do procesów starzenia się ludności. Można jednak przyjąć, że model ubezpieczeniowy realizowany jest w zdecydowanej większości krajów UE-27, a Niemcy stanowią wzorcowy przykład tego modelu 
[Pieńkowska-Kamieniecka, Rutecka, 2014, s. 19]. System emerytalny oparty na modelu Beveridge'a funkcjonuje w Wielkiej Brytanii i Irlandii. Natomiast systemy emerytalne oparte na modelu obywatelskim występują w Danii, Holandii oraz w Szwecji ${ }^{1}$.

\section{Starzenie się społeczeństwa jako wyzwanie dla systemów emerytalnych Unii Europejskiej}

\subsection{Proces starzenia się społeczeństwa i jego przejawy}

Właściwe relacje między ludnością w wieku przedprodukcyjnym, produkcyjnym i poprodukcyjnym są niezwykle ważne z punktu widzenia efektywności każdego systemu emerytalnego. Począwszy od połowy XX w., społeczeństwa krajów wysoko rozwiniętych, a zwłaszcza Europy Zachodniej, zaczęły się intensywnie starzeć, przez co zaburzają się te proporcje. Proces starzenia się społeczeństwa niesie ze sobą wiele zagrożeń i ma negatywny wpływ nie tylko na sytuację finansową systemu emerytalnego, ale i całych finansów publicznych. Rosnąca liczba osób uprawnionych do pobierania świadczeń emerytalnych znajduje odzwierciedlenie we wzroście wydatków publicznych na cele społeczne. Emerytury stanowią dużą i wciąż rosnącą część wydatków publicznych, średnio ponad 10\% PKB całej Unii Europejskiej, a w 2060 r. mogą stanowić nawet 12,5\% PKB [Biała księga, 2012, s. 4]. Utrzymujący się trend wzrostowy liczby emerytów będzie się z pewnością przyczyniał do wzrostu deficytu i długu publicznego w przyszłości.

Kryzys finansowy i gospodarczy, który dotknął głównie państwa UE-15 pokazał, że również kapitałowe systemy emerytalne nie są w pełni odporne na problemy ekonomiczne i społeczne. Nie są też wolne od skutków starzenia się społeczeństwa. W starzejącym się społeczeństwie coraz trudniej jest osiągać wysoką stopę wzrostu gospodarczego oraz wysokie stopy zwrotu z inwestycji kapitałowych. Generacja pracujących zawsze będzie miała określony wpływ na ostateczną wartość przyszłych emerytur. Z ekonomicznego punktu widzenia świadczenia emerytalne są bowiem transferami, polegającymi na przesunięciu w czasie dochodów pierwotnych producentów (pokolenie pracujące) do pokolenia niepracującego (emerytów). Świadczenia emerytalne są zatem pochodną wysokości i podziału PKB wytworzonego przez pokolenia aktywnych zawodowo. To, co mogą skonsumować emeryci, zawsze jest produkowane przez młodsze pokolenie pracujących, ponieważ nie ma możliwości przechowywania obecnej produkcji w długim okresie czasu [Żukowski, 2007, s. 116-117]. W związku z tym, kiedy na emeryturę przechodzić będą coraz liczniejsze rzesze pracowników, spadać będzie udział oszczędzających w populacji,

1 System emerytalny w Szwecji uważa się za przykład systemu innowacyjnego i stabilnego finansowo [Szczur, 2014, s. 34-45]. 
a co za tym idzie - będą też spadać ceny aktywów finansowych. Im większy będzie spadek oszczędzających, tym gwałtowniejszego spadku cen aktywów należy oczekiwać [Samborski, 2011, s. 34]. Potencjalne niskie stopy zwrotu z inwestycji funduszy emerytalnych będą przekładać się na niższe świadczenia emerytalne przy wzrastającym ryzyku.

Starzenie się populacji to proces demograficzny polegający na zwiększaniu odsetka osób starszych przy jednoczesnym zmniejszaniu odsetka dzieci w społeczeństwie danego kraju. Proces starzenia się populacji w Unii Europejskiej ilustruje piramida wiekowa ludności tych krajów. Porównując piramidę wiekową z roku 1991 oraz z 2011 r., można zaobserwować proces starzenia się, zarówno „od dołu”, jak i „od góry” (por. rys. 1). Starzenie „od dołu piramidy”, czyli zmniejszanie się liczby osób w wieku poniżej 30 lat, to efekt zmniejszającej się liczby urodzeń w kolejnych latach. Starzenie „od góry piramidy” wynika z wydłużającej się długości życia i zwiększania się procentowego udziału ludności w wieku starszym w ogólnej strukturze ludności [EU Employment..., 2013, s. 10].

W literaturze jako próg starości przyjmuje się najczęściej 60 lat (WHO) lub 65 lat (ONZ i Eurostat). Zgodnie z kryterium ONZ populację uznaje się za starą, jeżeli udział ludności w wieku 65 i więcej lat przekracza 7\%. Odsetek powyżej 10\% oznacza fazę zaawansowanej starości [Prognoza ludności..., 2014, s. 126]. Na tej podstawie można stwierdzić, że wszystkie kraje Unii Europejskiej wkroczyły w fazę zaawansowanej starości, pomimo że proces starzenia się demograficznego w poszczególnych krajach ma nierównomierny stopień zaawansowania (por. tab. 1). W 2010 r. największy udział ludzi starszych w populacji zanotowano w Niem-

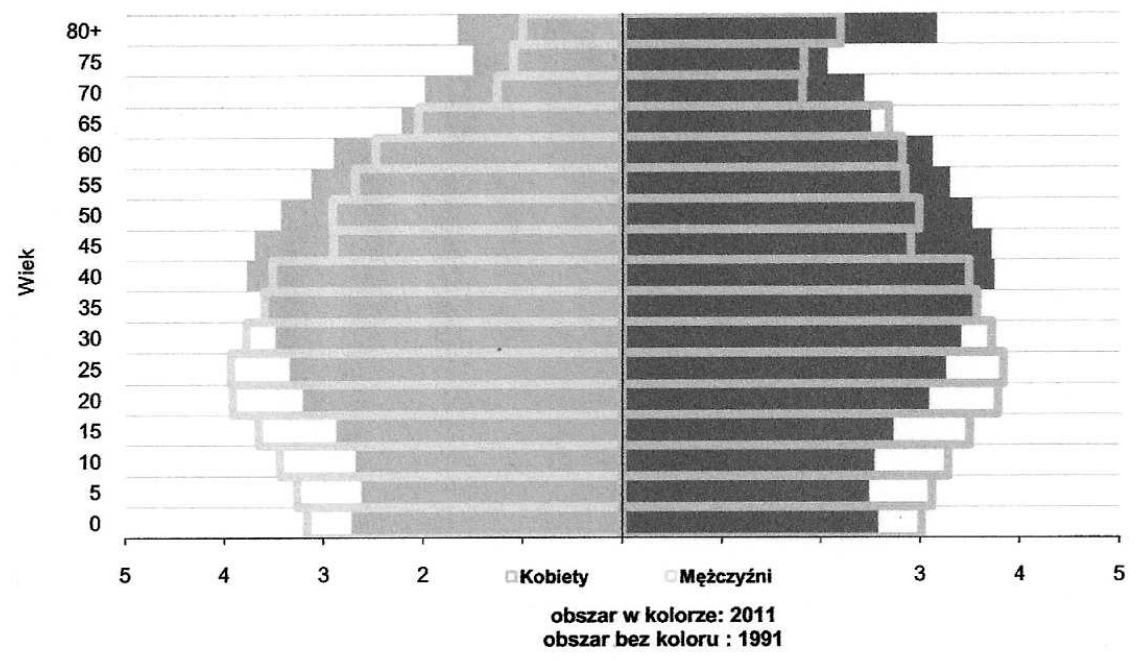

Rysunek 1. Piramida wiekowa dla krajów UE-27 w latach 1991 i 2011

Źródło: [Key..., 2013, s. 36]. 
czech i Włoszech (powyżej 20\%) oraz w Grecji (19,1\%). Nieco niższy udział ludzi starszych w ogólnej liczbie ludności był w Irlandii oraz w nowych krajach członkowskich Unii Europejskiej, takich jak: Polska, Słowacja, Rumunia, Litwa. Znamienny jest fakt, że tam, gdzie procesy starzenia rozpoczęły się najpóźniej, mają one gwałtowniejszy przebieg. Według prognoz najszybciej starzeć się będzie ludność w nowych krajach członkowskich Unii. Najwolniej będą się starzeć kraje „starej” Unii Europejskiej, takie jak: Wielka Brytania, Szwecja, Francja, Finlandia, Dania, Belgia (por. tab. 1).

Tabela 1. Udział osób w wieku powyżej 65 lat w populacji państw Unii Europejskiej w latach 1950-2010 oraz prognoza na lata 2020-2060

\begin{tabular}{|c|c|c|c|c|c|c|c|c|c|c|c|c|}
\hline & $\stackrel{\circ}{2}$ & $\stackrel{\circ}{\circ}$ & $\stackrel{2}{\stackrel{2}{a}}$ & $\begin{array}{l}\stackrel{\infty}{\infty} \\
\stackrel{9}{-}\end{array}$ & ஃ & 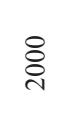 & $\stackrel{\circ}{\frac{1}{2}}$ & §ิ & ঙ̊ণ & 오 & $\stackrel{\circ}{\circ}$ & 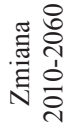 \\
\hline Austria & 10,4 & 12,2 & 14,1 & 15,4 & 15,0 & 15,5 & 17,6 & 19,9 & 24,4 & 27,7 & 29,2 & 11,5 \\
\hline Belgia & 11,0 & 12,0 & 13,4 & 14,4 & 15,0 & 17,0 & 17,2 & 19,3 & 22,5 & 24,3 & 25,5 & 8,3 \\
\hline Bułgaria & 6,7 & 7,5 & 9,6 & 11,9 & 13,1 & 16,6 & 17,6 & 21,0 & 24,3 & 27,6 & 32,6 & 15,0 \\
\hline Cypr & 6,1 & 6,0 & 10,1 & 9,8 & 10,2 & 10,2 & 13,2 & 16,6 & 19,7 & 21,3 & 27,6 & 14,4 \\
\hline Czechy & 8,2 & 9,2 & 12,0 & 13,5 & 12,5 & 13,7 & 15,4 & 19,8 & 22,1 & 25,1 & 30,6 & 15,3 \\
\hline Dania & 9,0 & 10,6 & 12,2 & 14,4 & 15,6 & 14,8 & 16,6 & 20,0 & 22,6 & 24,7 & 25,5 & 9,0 \\
\hline Estonia & 10,6 & 10,5 & 11,7 & 12,5 & 11,7 & 15,2 & 17,0 & 19,3 & 22,5 & 24,9 & 30,5 & 13,4 \\
\hline Finlandia & 6,7 & 7,2 & 9,2 & 11,9 & 13,4 & 14,9 & 17,3 & 22,3 & 21,4 & 25,5 & 27,1 & 9,8 \\
\hline Francja & 11,4 & 11,6 & 13,0 & 14,0 & 14,0 & 16,1 & 16,7 & 20,3 & 23,4 & 25,6 & 26,6 & 9,9 \\
\hline Grecja & 6,8 & 8,3 & 11,1 & 13,1 & 13,7 & 16,8 & 19,1 & 21,1 & 23,9 & 28,3 & 31,2 & 12,2 \\
\hline Hiszpania & 7,2 & 8,9 & 9,7 & 11,2 & 13,7 & 16,9 & 17,0 & 19,2 & 23,1 & 28,0 & 31,4 & 14,4 \\
\hline Holandia & 7,7 & 8,9 & 10,1 & 11,4 & 12,8 & 13,6 & 15,4 & 19,9 & 24,3 & 27,0 & 27,2 & 11,8 \\
\hline Irlandia & 10,9 & 11,2 & 11,2 & 10,8 & 11,4 & 11,2 & 11,5 & 14,6 & 17,7 & 20,3 & 24,9 & 10,5 \\
\hline Litwa & 9,4 & 7,9 & 10,1 & 11,3 & 10,9 & 13,9 & 16,1 & 17,7 & 22,3 & 25,6 & 31,2 & 15,1 \\
\hline Luksemburg & 9,8 & 10,8 & 12,6 & 13,7 & 13,4 & 14,2 & 14,0 & 15,8 & 19,6 & 23,0 & 26,4 & 12,5 \\
\hline Łotwa & 11,2 & 10,6 & 10,0 & 19,9 & 11,9 & 15,6 & 17,3 & 20,0 & 21,8 & 25,1 & 32,2 & 18,3 \\
\hline Malta & 5,8 & 7,1 & 8,6 & 9,5 & 9,8 & 11,3 & 15,1 & 20,7 & 24,2 & 25,1 & 31,2 & 16,1 \\
\hline Niemcy & 9,7 & 12,0 & 14,0 & 15,6 & 14,9 & 16,4 & 20,6 & 23,2 & 28,4 & 31,7 & 32,8 & 12,2 \\
\hline Polska & 5,2 & 5,7 & 8,2 & 10,1 & 10,1 & 12,2 & 13,5 & 18,2 & 22,6 & 25,3 & 34,6 & 21,0 \\
\hline Portugalia & 7,0 & 8,0 & 10,1 & 11,5 & 13,6 & 16,2 & 18,0 & 20,7 & 24,2 & 28,2 & 32,0 & 14,0 \\
\hline Rumunia & 5,3 & 6,7 & 8,6 & 10,3 & 10,4 & 13,4 & 14,9 & 17,6 & 20,2 & 25,7 & 34,8 & 19,9 \\
\hline Słowacja & 6,6 & 6,8 & 9,0 & 10,4 & 10,1 & 11,1 & 12,3 & 16,4 & 20,7 & 24,4 & 33,5 & 21,2 \\
\hline Słowenia & 7,0 & 7,8 & 9,9 & 11,4 & 11,1 & 14,0 & 16,5 & 20,0 & 24,4 & 27,7 & 31,5 & 15,0 \\
\hline Szwecja & 10,1 & 12,2 & 14,1 & 16,2 & 18,4 & 17,9 & 18,1 & 21,3 & 23,4 & 24,5 & 26,4 & 8,0 \\
\hline Węgry & 7,8 & 9,0 & 11,5 & 13,4 & 13,4 & 15,1 & 16,7 & 20,0 & 21,8 & 25,1 & 32,2 & 15,5 \\
\hline $\begin{array}{l}\text { Wielka } \\
\text { Brytania }\end{array}$ & 10,8 & 11,7 & 13,0 & 14,9 & 15,7 & 16,6 & 16,5 & 18,8 & 21,4 & 23,2 & 24,6 & 8,0 \\
\hline Włochy & 8,1 & 9,5 & 11,1 & 13,4 & 14,9 & 18,3 & 20,3 & 22,4 & 25,7 & 30,0 & 31,6 & 11,4 \\
\hline UE-27 & & 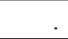 & & & & & 17,7 & 20,3 & 23,8 & 27,0 & 29,5 & 12,1 \\
\hline
\end{tabular}




\subsection{Wydłużająca się długość życia}

Długość życia Europejczyków stale się wydłuża. Największy wpływ na taki stan mają poprawiające się warunki bytowe oraz postęp w medycynie i ochronie zdrowia. Przewiduje się, że średnia oczekiwana długość życia w krajach EU-27 w okresie najbliższych 55 lat wzrośnie o 7,5 roku dla kobiet i o ponad 9 lat dla mężczyzn (por. tab. 2).

Tabela 2. Średnia oczekiwana długość życia w chwili urodzenia dla mieszkańców krajów UE-27

\begin{tabular}{|l|c|c|c|c|c|c|c|c|c|c|c|c|}
\hline & 2005 & 2006 & 2007 & 2008 & 2009 & 2010 & 2020 & 2030 & 2040 & 2050 & 2060 & Zmiana 2005-2060 \\
\hline $\mathrm{M}$ & 75,4 & 75,8 & 76,1 & 76,4 & 76,7 & 77,0 & 78,5 & 80,2 & 81,8 & 83,3 & 84,6 & 9,2 \\
\hline $\mathrm{K}$ & 81,6 & 82,0 & 82,2 & 82,4 & 82,6 & 82,9 & 84,0 & 85,4 & 86,7 & 87,9 & 89,1 & 7,5 \\
\hline
\end{tabular}

Źródło: opracowanie własne na podstawie [EU Employment..., 2013, s. 13; Economic..., 2012, s. 294-295].

Spośród mężczyzn urodzonych w 2010 r. najkrócej będą żyć Litwini (68 lat), a spośród kobiet - Bułgarki i Rumunki (77,5). Mężczyźni urodzeni w 2010 r. będą żyć najdłużej w Szwecji (por. wykres 1), a kobiety - we Francji, Włoszech i Hiszpanii (por. wykres 2). Jednocześnie przewiduje się, że oczekiwana długość życia w poszczególnych krajach europejskich będzie się stopniowo wyrównywać. Prognozuje się, że mężczyźni urodzeni w 2060 r., w większości krajów UE-27, przeżyją 84 lata, a kobiety przeżyją 88 lat. Największe zmiany nastąpią w takich krajach, jak Litwa i Łotwa. Tam oczekiwana długość życia mężczyzn wrośnie o prawie 13 lat. Natomiast w Bułgarii i Rumunii oczekiwana długość życia kobiet ma wzrosnąć o ponad 9 lat. Wydłużająca się długość życia powoduje, że stopa obciążenia demograficznego ludźmi starszymi również wzrasta, a wraz z nią rośnie zagrożenie utraty stabilności systemów emerytalnych i nieadekwatności emerytur.

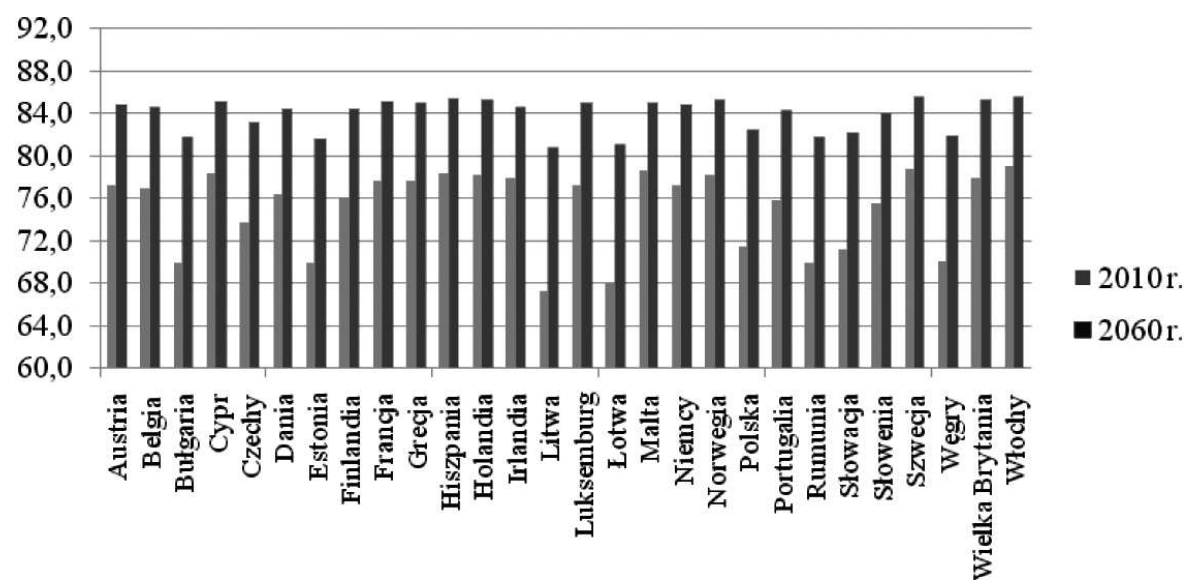

Wykres 1. Oczekiwana długość życia mężczyzn w chwili urodzenia dla krajów UE-27 w roku 2010 i 2060 


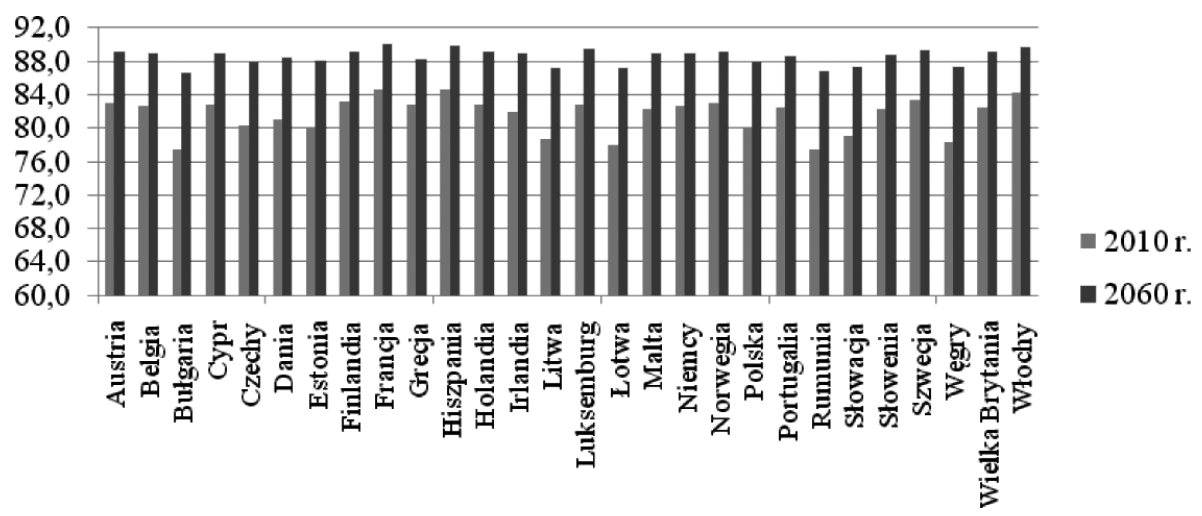

Wykres 2. Oczekiwana długość życia kobiet w chwili urodzenia dla krajów UE-27 w roku 2010 i 2060

Źródło: Opracowanie własne na podstawie [Economic..., 2012, s. 295].

Średnia wartość wskaźnika obciążenia demograficznego ludźmi starszymi ${ }^{2}$ dla UE-27 w 2012 r. wynosiła 26,8\%, podczas gdy w roku 1992 wskaźnik ten był znacznie niższy i wynosił $21,1 \%$. Na przestrzeni tych dziesięciu lat bardzo niekorzystnie zmieniły się również proporcje między wskaźnikiem obciążenia demograficznego ludźmi młodymi i starszymi. W 1992 r. średni wskaźnik obciążenia ludźmi młodymi w UE-27 był wyższy od średniego wskaźnika obciążenia ludźmi starszymi. W 2012 r. było już odwrotnie. Wskaźnik obciążenia demograficznego ludźmi starszymi wzrósł we wszystkich krajach (por. tab. 3).

Tabela 3. Struktura wiekowa ludności UE-27 w roku 1992 i w 2012

\begin{tabular}{|l|c|c|c|c|c|c|}
\hline \multirow{2}{*}{ Państwo } & \multicolumn{3}{|c|}{ Mediana wieku } & \multicolumn{2}{c|}{$\begin{array}{c}\text { Wskaźnik obciążenia } \\
\text { demograficznego ludźmi } \\
\text { młodymi (0-14 lat) }\end{array}$} & \multicolumn{2}{c|}{$\begin{array}{c}\text { Wskaźnik obciążenia } \\
\text { demograficznego ludźmi } \\
\text { starszymi (powyżej 65 lat) }\end{array}$} \\
\hline & 1992 & 2012 & 1992 & 2012 & 1992 & 2012 \\
\hline Austria & 35,6 & 42,4 & 26,1 & 21,4 & 22,1 & 26,2 \\
\hline Belgia & 36,6 & 41,0 & 27,3 & 25,9 & 22,9 & 26,4 \\
\hline Bułgaria & 37,1 & 42,7 & 29,4 & 19,7 & 20,8 & 27,8 \\
\hline Cypr & 31,2 & 35,8 & 40,4 & 23,3 & 17,3 & 18,1 \\
\hline Czechy & 35,6 & 40,1 & 30,8 & 21,2 & 19,1 & 23,4 \\
\hline Dania & 37,3 & 40,8 & 25,1 & 27,2 & 23,1 & 26,7 \\
\hline Estonia & 34,8 & 40,0 & 33,3 & 23,0 & 18,2 & 25,5 \\
\hline Finlandia & 36,9 & 42,2 & 28,6 & 25,2 & 20,3 & 27,7 \\
\hline Francja & 35,0 & 40,2 & 30,8 & 28,9 & 21,6 & 26,6 \\
\hline Grecja & 36,3 & 42,6 & 28,0 & 21,8 & 21,0 & 29,9 \\
\hline Hiszpania & 34,2 & 40,7 & 28,0 & 22,6 & 21,0 & 25,8 \\
\hline
\end{tabular}

2 Wskaźnik obciążenia demograficznego ludźmi starszymi (old-age dependency ratio) jest to relacja liczby ludności w wieku powyżej 65 lat do liczby ludności w wieku produkcyjnym (15-64 lat) wyrażona w procentach. 
Pobrane z czasopisma Annales H - Oeconomia http://oeconomia.annales.umcs.pl

Data: 26/04/2023 02:18:21

40

TERESA HANNA BEDNARCZYK

\begin{tabular}{|l|l|l|l|l|l|l|}
\hline Holandia & 34,9 & 41,3 & 26,6 & 26,1 & 18,8 & 24,4 \\
\hline Irlandia & 29,7 & 35,0 & 42,2 & 32,5 & 18,3 & 17,9 \\
\hline Litwa & 32,9 & 41,6 & 33,9 & 22,2 & 17,0 & 26,9 \\
\hline Luksemburg & 36,5 & 39,1 & 25,7 & 24,9 & 19,7 & 20,3 \\
\hline Lotwa & 35,0 & 41,8 & 32,5 & 21,3 & 18,6 & 27,7 \\
\hline Malta & 33,5 & 40,4 & 34,7 & 21,4 & 16,0 & 23,9 \\
\hline Niemcy & 37,7 & 45,0 & 23,8 & 20,0 & 21,8 & 31,2 \\
\hline Polska & 32,8 & 38,4 & 37,7 & 21,2 & 15,9 & 19,4 \\
\hline Portugalia & 34,8 & 42,3 & 29,0 & 22,5 & 20,9 & 29,6 \\
\hline Rumunia & 33,4 & 39,0 & 34,3 & 21,5 & 16,6 & 21,5 \\
\hline Słowacja & 31,6 & 37,7 & 37,8 & 21,5 & 16,0 & 17,8 \\
\hline Słowenia & 34,8 & 42,0 & 29,1 & 20,8 & 16,1 & 24,4 \\
\hline Szwecja & 38,4 & 40,8 & 28,5 & 25,9 & 27,7 & 29,2 \\
\hline Węgry & 36,8 & 40,3 & 29,1 & 21,1 & 20,4 & 24,6 \\
\hline Wielka Brytania & 35,9 & 39,8 & 29,7 & 26,7 & 24,3 & 25,9 \\
\hline Włochy & 37,6 & 43,8 & 22,3 & 21,5 & 22,4 & 31,6 \\
\hline Średnia UE-27 & $\mathbf{3 5 , 7}$ & $\mathbf{4 1 , 5}$ & $\mathbf{2 8 , 5}$ & $\mathbf{2 3 , 4}$ & $\mathbf{2 1 , 1}$ & $\mathbf{2 6 , 8}$ \\
\hline
\end{tabular}

Źródło: [EU Employment..., 2013, s. 19].

Według danych z 2012 r. najniższy poziom obciążenia demograficznego ludźmi starszymi był w takich krajach jak: Słowacja, Irlandia, Cypr i Polska (poniżej 20\%). Najwyższa relacja osób w wieku poprodukcyjnym do aktywnych zawodowo występuje w takich krajach, jak: Niemcy i Włochy (powyżej 30\%) oraz Grecja i Portugalia (prawie 30\%). O procesie starzenia się społeczeństwa europejskiego świadczy również mediana wieku ludności ogółem krajów UE-27, która systematycznie rosła, z 35,7 lat w 1992 r. do 41,5 w 2012 r. (por. tab. 3).

\subsection{Obniżające się wskaźniki dzietności}

Współczesnym problemem demograficznym jest również obniżający się poziom dzietności. Jeszcze w połowie 60. lat XX w. liczba żywych narodzin w Europie wynosiła 7,5 $\mathrm{mln}$. W $2011 \mathrm{r}$. liczba ta spadła do 5,2 mln. Niewielką poprawę zaobserwowano tylko w 2008 r. (5,4 mln). Jednakże w latach 2009-2011 zaobserwowano dalszy trend spadkowy w poziomie dzietności [EU Employment..., 2013, s. 10].

Obecnie współczynnik dzietności, czyli liczba narodzin przypadająca na jedną kobietę kształtuje się na znacznie niższym poziomie niż w drugiej połowie XX wieku. Od dawna współczynnik dzietności w większości krajów Unii Europejskiej jest niski (poniżej 1,5) lub bardzo niski (poniżej 1,3) i nie zapewnia zastępowalności pokoleń (powyżej 2). W $2010 \mathrm{r}$. współczynnik dzietności zapewniający zastępowalność pokoleń odnotowano jedynie we Francji i Irlandii. Jednak według prognoz na 2060 r. warunek ten nie będzie już spełniony w żadnym kraju członkowskim Unii Europejskiej (por. dane w tab. 4). 
Pobrane z czasopisma Annales H - Oeconomia http://oeconomia.annales.umcs.pl

Data: 26/04/2023 02:18:21

WYZWANIA DEMOGRAFICZNE DLA SYSTEMÓW EMERYTALNYCH W UNII EUROPEJSKIEJ

Tabela 4. Współczynniki dzietności w krajach Unii Europejskiej w wybranych latach oraz prognoza na lata 2020-2060

\begin{tabular}{|c|c|c|c|c|c|c|c|c|c|c|c|}
\hline & $\stackrel{8}{\circ}$ & $\stackrel{2}{2}$ & 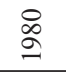 & $\stackrel{2}{\curvearrowright}$ & 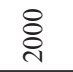 & $\stackrel{\circ}{\stackrel{\circ}{\sim}}$ & ণ্ণ & 尺े & $\stackrel{\text { \& }}{\stackrel{\text { }}{2}}$ & 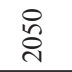 & 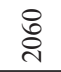 \\
\hline Austria & 2,69 & 2,29 & 1,65 & 1,46 & 1,36 & 1,44 & 1,43 & 1,46 & 1,49 & 1,52 & 1,56 \\
\hline Belgia & 2,54 & 2,25 & 1,68 & 1,62 & 1,67 & 1,86 & 1,84 & 1,84 & 1,84 & 1,84 & 1,84 \\
\hline Bułgaria & 2,31 & 2,17 & 2,05 & 1,82 & 1,26 & 1,49 & 1,58 & 1,60 & 1,63 & 1,65 & 1,67 \\
\hline Cypr & - & - & - & 2,41 & 1,64 & 1,44 & 1,52 & 1,55 & 1,57 & 1,60 & 1,62 \\
\hline Czechy & 2,09 & 1,92 & 2,08 & 1,90 & 1,14 & 1,49 & 1,52 & 1,55 & 1,57 & 1,60 & 1,62 \\
\hline Dania & 2,57 & 1,95 & 1,55 & 1,67 & 1,77 & 1,87 & 1,84 & 1,84 & 1,84 & 1,84 & 1,84 \\
\hline Estonia & - & - & - & 2,05 & 1,38 & 1,63 & 1,64 & 1,66 & 1,67 & 1,69 & 1,70 \\
\hline Finlandia & 2,72 & 1,83 & 1,63 & 1,78 & 1,73 & 1,87 & 1,86 & 1,86 & 1,86 & 1,86 & 1,86 \\
\hline Francja & 2,73 & 2,47 & 1,95 & 1,78 & 1,87 & 2,02 & 1,99 & 1,98 & 1,97 & 1,96 & 1,95 \\
\hline Grecja & 2,23 & 2,40 & 2,23 & 1,40 & 1,26 & 1,51 & 1,55 & 1,57 & 1,59 & 1,62 & 1,64 \\
\hline Hiszpania & - & - & 2,20 & 1,36 & 1,23 & 1,38 & 1,43 & 1,46 & 1,50 & 1,53 & 1,56 \\
\hline Holandia & 3,12 & 2,57 & 1,60 & 1,62 & 1,72 & 1,79 & 1,79 & 1,80 & 1,80 & 1,81 & 1,81 \\
\hline Irlandia & 3,78 & 3,85 & 3,21 & 2,11 & 1,89 & 2,07 & 2,05 & 2,04 & 2,02 & 2,00 & 1,99 \\
\hline \begin{tabular}{|l|} 
Litwa \\
\end{tabular} & - & 2,40 & 1,99 & 2,03 & 1,39 & 1,55 & 1,57 & 1,59 & 1,61 & 1,63 & 1,66 \\
\hline Luksemburg & 2,29 & 1,97 & 1,50 & 1,60 & 1,76 & 1,63 & 1,61 & 1,63 & 1,65 & 1,66 & 1,68 \\
\hline Lotwa & - & - & - & - & - & 1,17 & 1,35 & 1,39 & 1,43 & 1,47 & 1,51 \\
\hline Malta & - & - & 1,99 & 2,04 & 1,70 & 1,38 & 1,47 & 1,50 & 1,53 & 1,56 & 1,59 \\
\hline Niemcy & - & - & $\begin{array}{llll}- & \\
-\end{array}$ & - & 1,38 & 1,39 & 1,40 & 1,43 & 1,47 & 1,50 & 1,54 \\
\hline Polska & - & - & - & 2,06 & 1,37 & 1,38 & 1,43 & 1,46 & 1,50 & 1,53 & 1,56 \\
\hline \begin{tabular}{|l|} 
Portugalia \\
\end{tabular} & 3,16 & 3,01 & 2,25 & 1,56 & 1,55 & 1,36 & 1,36 & 1,40 & 1,44 & 1,47 & 1,51 \\
\hline \begin{tabular}{|l|} 
Rumunia \\
\end{tabular} & - & - & 2,43 & 1,83 & 1,31 & 1,33 & 1,41 & 1,45 & 1,48 & 1,51 & 1,55 \\
\hline Słowacja & 3,04 & 2,41 & 2,32 & 2,09 & 1,30 & 1,40 & 1,44 & 1,48 & 1,51 & 1,54 & 1,57 \\
\hline \begin{tabular}{|l|} 
Słowenia \\
\end{tabular} & - & - & - & 1,46 & 1,26 & 1,57 & 1,56 & 1,58 & 1,60 & 1,63 & 1,65 \\
\hline Szwecja & - & 1,92 & 1,68 & 2,13 & 1,54 & 1,98 & 1,93 & 1,92 & 1,92 & 1,91 & 1,90 \\
\hline Węgry & 2,02 & 1,98 & 1,91 & 1,87 & 1,32 & 1,25 & 1,36 & 1,40 & 1,44 & 1,47 & 1,51 \\
\hline Wielka Brytania & - & - & 1,90 & 1,83 & 1,64 & 1,98 & 1,93 & 1,93 & 1,92 & 1,91 & 1,91 \\
\hline Włochy & 2,37 & 2,38 & 1,64 & 1,33 & 1,26 & 1,41 & 1,45 & 1,48 & 1,51 & 1,54 & 1,57 \\
\hline
\end{tabular}

Źródło: [EU Employment..., 2013, s. 11].

Powodów niskiego poziomu dzietności należy się doszukiwać przede wszystkim w zmianie postaw i systemu wartości, które dokonują się, począwszy od końca II wojny światowej, zwłaszcza wśród ludzi młodych. W 60. latach XX w. rozpoczęły się intensywne przeobrażenia $\mathrm{w}$ sferze modelu funkcjonowania rodzin, wzroście znaczenia kobiet na rynku pracy, opóźnienia wieku wchodzenia w związki małżeńskie, odkładanie w czasie decyzji o rodzicielstwie i wydłużanie się wieku rodzenia pierwszego dziecka. W 2002 r. statystyczna kobieta rodziła pierwsze dziecko w wieku 29,2 lat, zaś w roku 2011 - już w średnim wieku 30 lat [EU Employment..., 2013, s. 11].

Reasumując, należy zauważyć, że kondycja współczesnych systemów emerytalnych jest silnie uzależniona od procesów demograficznych. Obecnie obserwowane tendencje w tym obszarze nie napawają optymizmem. Zarówno w Polsce, jak i w innych krajach Unii Europejskiej z jednej strony rośnie oczekiwana długość życia, z drugiej zaś maleje wielkość populacji w wieku przedprodukcyjnym, a współczynnik 
dzietności utrzymuje się na poziomie niezapewniającym zastępowalności pokoleń. Struktura wiekowa społeczeństwa zmienia się zatem bardzo niekorzystnie. Rośnie udział potencjalnych beneficjentów systemu emerytalnego przy malejącej liczbie osób płacących składki ubezpieczeniowe. Wraz z wydłużającym się wiekiem rośnie także przeciętny okres pobierania emerytur. Niepokojącym zjawiskiem jest dalsze pogłębianie się tych dysproporcji, które uniemożliwiają systemom emerytalnym wypełnianie zobowiązań emerytalnych na satysfakcjonującym poziomie.

\section{Wybrane inicjatywy na szczeblu unijnym dotyczące rozwiązania problemów emerytalnych}

\subsection{Metoda otwartej koordynacji w dziedzinie emerytur}

Wobec zjawiska starzenia się społeczeństwa krajów europejskich oraz negatywnych procesów z tym związanych zintensyfikowano współpracę w obszarze zabezpieczenia emerytalnego na poziomie europejskim. Od $2001 \mathrm{r}$. w krajach Unii Europejskiej realizowana jest tzw. metoda otwartej koordynacji (ang. open method of coordination) systemów zabezpieczenia społecznego. Metoda ta stwarza ramy dla bliższej współpracy, ale nie zwalnia poszczególnych krajów członkowskich z odpowiedzialności za modernizację swoich systemów emerytalnych. Otwarta metoda koordynacji obejmuje uzgodnienie podstawowych, wspólnych celów, przełożenie tych celów na strategie polityki poszczególnych państw, okresowe monitorowanie postępu (w ramach procesu wzajemnego uczenia się), w miarę możliwości, także na podstawie wspólnie uzgodnionych i zdefiniowanych wskaźników [Council of the European Union, 2001].

W grudniu 2001 r. na posiedzeniu Rady Europejskiej w Laeken ustalono zestaw podstawowych wspólnych celów dotyczących emerytur, takich jak: zapewnienie adekwatności i trwałości emerytur oraz modernizacji systemów emerytalnych [Council of the European Union, 2001] $]^{3}$.Zdaniem Komisji Europejskiej emerytury adekwatne to takie, które są w stanie realizować cele ekonomiczne i społeczne. Systemy emerytalne będą trwałe (stabilne), jeżeli zostaną oparte na prawidłowym finansowaniu krajowych systemów emerytalnych. Cel trzeci dotyczy modernizacji systemów emerytalnych w odpowiedzi na zmieniające się potrzeby otoczenia ekonomicznego, społecznego oraz potrzeby jednostek ${ }^{4}$.

\footnotetext{
3 Zgodnie z zasadą subsydiarności poszczególne kraje członkowskie same decydują o sposobie realizacji tych celów. Zostały one jednak zobligowane do sporządzania raportów strategicznych, w których prezentują założenia i skutki reform swoich systemów emerytalnych. Wszystkie te raporty podlegają wspólnej ocenie przez KE oraz Radę. Wymiana informacji ma doprowadzić do wyłonienia liderów (swoistych benchmarków), do których pozostałe kraje powinny równać.

4 Ogromna częstotliwość tych zmian jest charakterystyczna m.in. dla systemu brytyjskiego [Czepulis-Rutkowska, 2014, s. 13-18].
} 
Reformowanie systemów emerytalnych w państwach członkowskich Unii Europejskiej stało się faktem, chociaż zakres i głębokość wprowadzanych zmian zostały mocno zróżnicowane (por. tab. 5). Radykalne przekształcenie systemów repartycyjnych w systemy kapitałowe nie jest możliwe z uwagi na bardzo wysokie (nieakceptowane) koszty transakcyjne, związane z koniecznością podwójnego obciążenia pokolenia ludzi młodych w okresie przejściowym. W większości państw członkowskich UE-15 starano się zapewnić zbilansowanie przychodów i wydatków emerytalnych w dłuższym okresie czasu za pomocą reform stosunkowo łagodnych, zwanych parametrycznymi, które polegały przede wszystkim na [Zielona księga..., 2010, s. 5]:

- wprowadzaniu zachęt finansowych do podejmowania pracy w większym wymiarze i dłuższym pozostawaniu na rynku pracy,

- ograniczaniu możliwości wcześniejszego kończenia aktywności zawodowej,

- wspieraniu równości płci na rynku pracy,

- ułatwianiu dostępu do świadczeń emerytalnych grupom znajdującym się w trudnej sytuacji oraz zwiększaniu wsparcia finansowego dla najuboższych grup emerytów.

Reformy systemowe niosą daleko idące konsekwencje. Zostały wprowadzone w krajach takich, jak: Szwecja, Polska, Litwa, Łotwa oraz Włochy. Polegają one

Tabela 5. Zreformowane systemy emerytalne w krajach Unii Europejskiej (UE-27) według stanu z 2010 r.

\begin{tabular}{|c|c|c|c|c|c|}
\hline \multicolumn{2}{|c|}{$\begin{array}{c}\text { Powszechny publiczny system } \\
\text { emerytalny (I filar) }\end{array}$} & \multicolumn{4}{|c|}{ Dodatkowe systemy emerytalne (II i III flar) } \\
\hline Model & $\begin{array}{l}\text { Podstawa } \\
\text { uprawnień/ } \\
\text { wysokość } \\
\text { emerytury }\end{array}$ & \multicolumn{2}{|c|}{ Dobrowolny } & $\begin{array}{l}\text { Obowiązkowy } \\
\text { (p) publiczny } \\
\text { (z) zakładowy }\end{array}$ & $\begin{array}{l}\text { Dobrowolny } \\
\text { (z) zakładowy } \\
\text { (i) indywi-dualny }\end{array}$ \\
\hline $\begin{array}{l}\text { Model } \\
\text { Bismarcka } \\
\text { Emerytura } \\
\text { zróżnicowana }\end{array}$ & $\begin{array}{l}\text { Ubezpieczenie/ } \\
\text { dochody z pracy } \\
\text { (DB) }\end{array}$ & $\begin{array}{l}\text { Austria } \\
\text { Belgia } \\
\text { Czechy* } \\
\text { Cypr } \\
\text { Grecja } \\
\text { Finlandia } \\
\text { Hiszpania }\end{array}$ & $\begin{array}{l}\text { Litwa* } \\
\text { Luksem-burg } \\
\text { Malta } \\
\text { Niemcy } \\
\text { Portugalia } \\
\text { Słowenia* }\end{array}$ & $\begin{array}{l}\text { Bułgaria } \\
\text { Estonia } \\
\text { Rumunia } \\
\text { Słowacja } \\
\text { Węgry } \\
\text { Francja (z) }\end{array}$ & $\begin{array}{l}\text { Bułgaria (i, z) } \\
\text { Estonia (i) } \\
\text { Rumunia ( z) } \\
\text { Słowacja (i) } \\
\text { Węgry (i) }\end{array}$ \\
\hline $\begin{array}{l}\text { Według } \\
\text { dochodów } \\
\text { w okresie } \\
\text { ubezpieczenia }\end{array}$ & $\begin{array}{l}\text { Ubezpieczenia/ } \\
\text { składki (NDC) }\end{array}$ & Włochy & Litwa & $\begin{array}{l}\text { Łotwa } \\
\text { Polska Szwecja }\end{array}$ & $\begin{array}{l}\text { Lotwa (i) } \\
\text { Polska (i, z) } \\
\text { Szwecja (i, z) }\end{array}$ \\
\hline $\begin{array}{l}\text { Model } \\
\text { Beveridge'a }\end{array}$ & $\begin{array}{l}\text { Opłacanie } \\
\text { składek } \\
\text { (ubezpieczenie) }\end{array}$ & Irlandia & & Wielka Brytania (p) & $\begin{array}{l}\text { Wielka Bry-tania } \\
(\mathrm{i}, \mathrm{z})\end{array}$ \\
\hline $\begin{array}{l}\text { Emerytura } \\
\text { jednolita }\end{array}$ & Zamieszkiwanie & & & & $\begin{array}{l}\text { Dania (z) } \\
\text { Holandia (z) }\end{array}$ \\
\hline
\end{tabular}

* Kraje, które zachowały system repartycyjny bez obowiązkowych funduszy emerytalnych.

DB - formuła zdefiniowanego świadczenia

NDC - formuła zdefiniowanej składki

Źródło: [M. Żukowski 2013, s. 94]. 
na zastąpieniu formuły zdefiniowanego świadczenia (DB) w systemie repartycyjnym na formułę zdefiniowanej składki (NDC) w tym systemie. Zgodnie z formułą zdefiniowanego świadczenia emerytura państwowa przysługuje pracownikom po osiągnięciu określonego wieku emerytalnego, a jej wysokość jest uzależniona od długości stażu ubezpieczeniowego i zarobków osiąganych w przyjętym okresie. Formuła zdefiniowanej składki (pracownik orientuje się, jaką składkę płaci, ale nie zna wysokości swojej przyszłej emerytury) czyni emerytury całkowicie zależnymi od wysokości wpłaconych składek emerytalnych oraz dalszej przewidywanej długości trwania życia - innej dla obydwu płci. W związku z tym, z jednej strony system emerytalny lepiej dostosowuje się do zmian demograficznych oraz skuteczniej zachęca do późniejszego odchodzenia z rynku pracy, przez co ma szansę być stabilny finansowo w długim okresie. Z drugiej jednak strony - formuła zdefiniowanej składki jest korzystna dla osób dobrze zarabiających, pracujących stale na etatach i niemających przerw w zatrudnieniu. Tymczasem na współczesnym rynku pracy występują różne formy elastycznego zatrudnienia i dlatego formuła ta nie jest korzystna dla pracowników nisko wynagradzanych, osób pracujących na podstawie innych umów niż umowa o pracę ${ }^{5}$. Nie jest też korzystna dla pracowników mających przerwy w pracy, związane np. z rodzicielstwem lub bezrobociem. Zachodzi obawa, że w Polsce około połowa populacji ubezpieczonych w systemie publicznym może nie być w stanie wypracować emerytur minimalnych, chroniących ich przed ubóstwem.

Najdalej idące są jednak reformy strukturalne, wprowadzone w krajach UE-12 (poza Czechami i Litwą) oraz w Szwecji i częściowo we Włoszech, które polegają na przekształcaniu jednowarstwowych (jednofilarowych) systemów emerytalnych w systemy wielowarstwowe (wielofilarowe). W tych krajach wprowadzono (nieobecne wcześniej) otwarte fundusze emerytalne (OFE) oraz przypisano dużą rolę prywatnym systemom kapitałowym, jako źródłom uzupełniającym emerytury z publicznego systemu ubezpieczeniowego.

Państwa członkowskie UE nie zakończyły jeszcze zalecanego procesu dostosowawczego, ale dziś już można wysnuć następujący wniosek. Dotychczasowe refor-

\footnotetext{
5 Dotychczasowy stan prawny w Polsce nie obejmował generalnie umów cywilno-prawnych obowiązkiem odprowadzania składek emerytalnych. Dopiero w październiku 2014 r. Sejm uchwalił nowelizację ustawy o systemie ubezpieczeń społecznych oraz niektórych innych ustaw, na mocy której rozszerzono zakres ubezpieczenia społecznego. Od 1 stycznia 2016 r. wejdą w życie zmiany w zasadach podlegania ubezpieczeniom emerytalnym przez osoby wykonujące umowy zlecenia (przez które należy rozumieć umowę zlecenie, umowę agencyjną albo inną umowę, do której stosuje się przepisy dotyczące zlecenia) oraz w przypadku występowania kilku tytułów do ubezpieczenia. Dotychczasowy stan prawny, w którym w przypadku wykonywania kilku umów zleceń opłacano składki z tytułu umowy o najniższym wynagrodzeniu, modyfikuje się przez wprowadzenie progu dla podstawy wymiaru składek w wysokości minimalnego wynagrodzenia oraz sumowanie podstaw wymiaru składki z kilku tytułów, jeżeli podstawa wymiaru składki z jednego tytułu byłaby niższa niż minimalne wynagrodzenie. Rozszerzenie obowiązku ubezpieczenia dotyczy także jednoczesnego wykonywania umów zleceń z podejmowaniem innej działalności [Ustawa z dnia 13 października 1998 r. o systemie ubezpieczeń społecznych (tekst jednolity: Dz. U. z 2015 r., poz. 121)].
} 
my publicznych systemów emerytalnych będą skutkować w przyszłości spadkiem tzw. stóp zastąpienia dochodów netto, czyli relacji średniej emerytury do średniego wynagrodzenia w gospodarce. Prognozuje się, że w latach 2008-2048 teoretyczne stopy zastąpienia publicznych systemów emerytalnych obniżą się w większości krajów Unii Europejskiej, przypuszczalnie w Portugalii (o ponad 20\%), Szwecji, Polsce i Francji (o 15\%), Włoszech (o 14\%), Czechach (o 12\%), Danii (o 11\%), Grecji (o 9\%), Niemczech (o ok. 8\%), Finlandii i Malcie (o ok. 7\%), na Węgrzech, w Słowacji i na Łotwie (o ok. 5\%), w Belgii i na Litwie (o ok. 1\%). Wzrost stóp zastąpienia prognozowany jest tylko w kilku krajach UE, takich jak: Hiszpania i Wielka Brytania (ok. 1\%), Estonia (ok. 7\%), Cypr (14\%), Bułgaria (16\%), Słowenia (17\%) i Rumunia (25\%), [Biała księga..., 2012, s. 5].

\subsection{Wydłużanie wieku emerytalnego}

W krajach Unii Europejskiej, zarówno oficjalny minimalny wiek emerytalny, jak i przeciętny faktyczny wiek emerytalny są zróżnicowane (por. tab. 6). Ponadto w większości krajów obserwuje się albo wydłużanie minimalnego wieku emerytalnego, albo odchodzenie od różnic $w$ tym zakresie między kobietami i mężczyznami. Nadal w wielu krajach europejskich istnieją rozwiązania pozwalające, przy spełnieniu określonych warunków, nabyć uprawnienia emerytalne wcześniej, niż wynikałoby to z ustawowego wieku emerytalnego. Tym samym przeciętny, faktyczny wiek zaprzestania aktywności zawodowej różni się od wieku teoretycznego i to dość znacznie (por. tab. 6).

Mężczyźni kończą swoją pracę zawodową faktycznie najpóźniej w Portugalii i Szwecji, a kobiety w Portugalii, Szwecji i Hiszpanii. W Polsce wcześniejsze emerytury są dość popularne. W latach 1970-2009 faktyczny wiek przechodzenia na emeryturę obniżył się niemal o 13 lat, z 72,9 do 60,1 [GUS, 2010, s. 10]. A zatem minimalny wiek emerytalny jest umową społeczną usankcjonowaną prawem. W Polsce, na podstawie obecnie obowiązujących przepisów, wiek emerytalnych wszystkich Polaków bez względu na płeć wynosi 67 lat [Ustawa z dnia 11 maja 2012 r.]. Sprawą niezwykle trudną jest ustalenie wieku emerytalnego na takim poziomie, by z jednej strony był on akceptowalny społecznie, a z drugiej - poprzez uzależnienie wielkości gromadzonych oszczędności od okresu aktywności zawodowej - przekładał się na adekwatne zaspokajanie potrzeb uczestników systemu. Dlatego też określenie jego granicy powinno być poprzedzone szczegółową analizą przesłanek o charakterze prawnym, ekonomicznym i społecznym.

Jeżeli zasoby pracy zwiększają się szybciej niż liczba miejsc pracy w gospodarce, można określać granice wieku emerytalnego na niskim poziomie, aby ograniczać bezrobocie wśród ludzi młodych i zwiększać ich szanse na zatrudnienie. Jeżeli jednak, na skutek starzenia się społeczeństwa, nastąpi kurczenie się zasobów pracy, co ma negatywne konsekwencje z punktu widzenia wzrostu gospodarczego, to należy wydłużać okres aktywności zawodowej oraz zwiększać wykorzystanie potencjału pracowniczego ludzi starszych. 
Pobrane z czasopisma Annales H - Oeconomia http://oeconomia.annales.umcs.pl

Data: 26/04/2023 02:18:21

TERESA HANNA BEDNARCZYK

Tabela 6. Wiek emerytalny w krajach Unii Europejskiej (stan na wrzesień 2013 r.)

\begin{tabular}{|c|c|c|c|c|c|}
\hline \multirow[t]{2}{*}{ Kraj } & \multicolumn{2}{|c|}{$\begin{array}{c}\text { Oficjalny minimalny } \\
\text { wiek emerytalny }\end{array}$} & \multicolumn{2}{|c|}{$\begin{array}{l}\text { Przeciętny, faktyczny } \\
\text { wiek emerytalny }\end{array}$} & \multirow[t]{2}{*}{ Uwagi } \\
\hline & Kobiet & Mężczyzn & Kobiet & Mężczyzn & \\
\hline Austria & 65 & 65 & 59,4 & 61,9 & $\begin{array}{l}\text { Zrównanie wieku mężczyzn i kobiet ma } \\
\text { być osiągnięte między } 2024 \text { a } 2033 \text { r. }\end{array}$ \\
\hline Belgia & 65 & 65 & 58,7 & 59,6 & - \\
\hline Bułgaria & 60 & 63 & & & $\begin{array}{l}\text { Stopniowe wydłużanie wieku do } 65 \text { lat } \\
\text { (mężczyźni) i 63lat (kobiety) }\end{array}$ \\
\hline Cypr & 65 & 65 & & & 63 lata dla górników \\
\hline Czechy & $57-61$ & 62 & 59,8 & 63,1 & $\begin{array}{l}\text { Wiek kobiet zróżnicowany w zależności od } \\
\text { liczby dzieci: } \\
61 \text { lat }- \text { brak dzieci } \\
60 \text { lat }-1 \text { dziecko } \\
59-2 \text { dzieci } \\
58-3 \text { i } 4 \text { dzieci } \\
57-5 \text { i więcej dzieci } \\
\end{array}$ \\
\hline Dania & 65 & 65 & 61,9 & 63,4 & $\begin{array}{l}\text { Podwyższanie wieku do } 67 \text { lat (w latach } \\
\text { 2024-2027) }\end{array}$ \\
\hline Estonia & 61 & 63 & 62,6 & 63,6 & Podwyższanie do 65 lat \\
\hline Finlandia & 65 & 65 & 61,9 & 61,8 & \\
\hline Francja & 65 & 65 & 60,0 & 59,7 & \\
\hline Grecja & 64 & 65 & 60,3 & 61,9 & $\begin{array}{l}62 \text { lata dla osób z 40-letnim okresem } \\
\text { ubezpieczenia }\end{array}$ \\
\hline Hiszpania & 65 & 65 & 63,2 & 62,3 & Podwyższenie do 67 lat \\
\hline Holandia & 65 & 65 & 62,3 & 63,6 & Podwyższenie do 67 lat \\
\hline Irlandia & 66 & 66 & 62,6 & 64,6 & \\
\hline Litwa & 60 & 62 & & & Podwyższanie do 65 lat \\
\hline Luksemburg & 65 & 65 & 59,6 & 57,6 & \\
\hline Łotwa & 62 & 62 & & & Podwyższenie do 65 lat \\
\hline Niemcy & 65 & 65 & 61,6 & 62,1 & Podwyższenie do 67 lat \\
\hline Polska & $67^{*}$ & $67 *$ & 60,2 & 62,3 & *Na dzień 8.09.2014 r. \\
\hline Portugalia & 65 & 65 & 66,4 & 68,4 & \\
\hline Rumunia & 59 & 64 & & & $\begin{array}{l}\text { Podnoszony do } 65 \text { - mężczyźni, } \\
63 \text { - kobiety }\end{array}$ \\
\hline Słowacja & 60 & 62 & 58,7 & 60,9 & $\begin{array}{l}\text { Od } 2017 \text { r. podnoszenie wieku w zależności } \\
\text { od oczekiwanej długości życia }\end{array}$ \\
\hline Słowenia & 61 & 63 & 60,6 & 62,9 & - \\
\hline Szwecja & 65 & 65 & 64,2 & 66,1 & $\begin{array}{l}\text { Możliwość pracy do 67. r. za zgodą } \\
\text { pracodawcy }\end{array}$ \\
\hline Węgry & 64 & 64 & 59,6 & 60,6 & Podnoszenie do 65 lat \\
\hline Wielka Brytania & 61 & 65 & 63,2 & 63,7 & Zrównanie wieku \\
\hline
\end{tabular}

Źródło: Opracowanie własne na podstawie [Pensions..., 2013]

W obliczu dynamicznie zmieniających się uwarunkowań społecznych i gospodarczych, a przede wszystkim demograficznych ustalanie sztywnego wieku emerytalnego traci sens. Obecnie wskazane jest raczej uelastycznianie momentu przechodzenia na emeryturę, a także umożliwienie stopniowego opuszczania rynku pracy [Jurek, 2011, s. 24]. Przykładowo w Szwecji dobrze sprawdza się elastyczny wiek przechodzenia na emeryturę. Istnieje tam możliwość zakończenia aktywności zawodowej już w momencie osiągnięcia 61 lat lub kontynuowania jej do 67. r. życia. Należy przy tym brać pod uwagę kwestie zdrowotne obywateli oraz ich zdolność 
do świadczenia pracy, a także ekonomiczne możliwości państwa do zapewnienia odpowiednich warunków zatrudnienia dla poszczególnych grup wiekowych. Istotne jest również powiązanie rozwiązań dotyczących wieku emerytalnego z dotychczas obowiązującymi odrębnymi przepisami, odnoszącymi się do polityki zatrudnienia i regulującymi rynek pracy [Uścińska, 2012, s. 24].

\subsection{Zwiększanie aktywności zawodowej}

Powodzenie reform emerytalnych polegających na wydłużaniu wieku emerytalnego zależy przede wszystkim od rozwoju rynku pracy. Komisja Europejska wzywa do przeprowadzenia reform mających na celu poprawę perspektyw wzrostu gospodarczego Europy i większą wydajność pracy, głównie poprzez zwiększenie współczynników zatrudnienia. Jeśli chodzi o osoby w wieku produkcyjnym (20-64) to współczynnik zatrudnienia powinien wzrosnąć w roku 2020 do $75 \%$, a w roku 2013 - do 77,9\%. Reformy emerytalne powinny ograniczyć liczbę osób zagrożonych ubóstwem o co najmniej $20 \mathrm{mln}$ [UE Employment..., 2013, s. 28].

Tabela 7. Wskaźniki zatrudnienia pracowników w wieku 55-64 lat w państwach członkowskich UE-27 w latach 2010-2011 (w \%)

\begin{tabular}{|c|c|c|c|}
\hline Przedział wskaźnika zatrudnienia & Kraj & 2010 & 2011 \\
\hline Wskaźnik zatrudnienia $30,2-38,0$ & $\begin{array}{l}\text { Malta } \\
\text { Polska } \\
\text { Węgry } \\
\text { Słowenia } \\
\text { Włochy } \\
\text { Belgia } \\
\end{array}$ & $\begin{array}{l}30,2 \\
34,0 \\
34,4 \\
35,0 \\
36,0 \\
37,3 \\
\end{array}$ & $\begin{array}{l}31,7 \\
36,9 \\
35,8 \\
31,2 \\
37,9 \\
38,7 \\
\end{array}$ \\
\hline Wskaźnik zatrudnienia $38,0-46,0$ & $\begin{array}{l}\text { Luksemburg } \\
\text { Francja } \\
\text { Słowacja } \\
\text { Rumunia } \\
\text { Grecja } \\
\text { Austria } \\
\text { Bułgaria } \\
\text { Hiszpania } \\
\end{array}$ & $\begin{array}{l}39,6 \\
39,7 \\
40,5 \\
41,1 \\
42,3 \\
42,4 \\
43,5 \\
43,6 \\
\end{array}$ & $\begin{array}{l}39,3 \\
41,4 \\
41,5 \\
40,0 \\
39,4 \\
41,5 \\
43,9 \\
44,5 \\
\end{array}$ \\
\hline Wskaźnik zatrudnienia $46,0-54,0$ & $\begin{array}{l}\text { Czechy } \\
\text { Lotwa } \\
\text { Litwa } \\
\text { Portugalia } \\
\text { Irlandia } \\
\text { Holandia } \\
\text { Estonia } \\
\end{array}$ & $\begin{array}{l}46,5 \\
48,2 \\
48,6 \\
49,2 \\
50,0 \\
53,7 \\
53,8 \\
\end{array}$ & $\begin{array}{l}47,6 \\
51,1 \\
50,5 \\
47,9 \\
50,0 \\
56,1 \\
57,2 \\
\end{array}$ \\
\hline Wskaźnik zatrudnienia $54,0-62,0$ & \begin{tabular}{|l|} 
Finlandia \\
Cypr \\
Wielka Brytania \\
Dania \\
Niemcy \\
\end{tabular} & $\begin{array}{l}56,2 \\
56,5 \\
57,1 \\
57,6 \\
57,7 \\
\end{array}$ & $\begin{array}{l}57,0 \\
55,2 \\
56,7 \\
59,5 \\
59,9 \\
\end{array}$ \\
\hline \multirow[t]{2}{*}{ Wskaźnik zatrudnienia $62,0-70,5$} & Szwecja & 70,5 & 72,3 \\
\hline & UE-27 & 46,3 & 47,4 \\
\hline
\end{tabular}


Ambicją Komisji Europejskiej jest również zachęcenie krajów członkowskich Unii Europejskiej do przeprowadzenia niezbędnych działań mających na celu doprowadzenie do poprawy wskaźnika zatrudnienia, nie tylko osób w wieku przedemerytalnym, ale także kobiet, imigrantów i młodzieży. Komisja Europejska widzi w tym możliwość zneutralizowania wpływu starzenia się społeczeństwa na obciążenia PKB wydatkami emerytalnymi.

Współczynniki zatrudnienia w grupach wiekowych zbliżonych do wieku emerytalnego są niskie w większości krajów UE-27, jednak powoli rosną, co napawać może pewnym optymizmem (por. tab. 7). Średni wskaźnik zatrudnienia w UE-27 w przedziale wiekowym 55-64 zwiększył się z 37,7\% w 2001 r. do 47,4\% w roku 2011. Świadczyć to może o powolnym odwracaniu tendencji do przechodzenia na wcześniejsze emerytury. Warto podkreślić, że Szwecja ma najwyższy wskaźnik zatrudnienia osób w grupach wiekowych zbliżonych do wieku emerytalnego, znacznie wyższy niż średnia dla UE-27.

\section{Zakończenie}

Współczesne systemy emerytalne w krajach Unii Europejskiej poddawane są wpływom wielu negatywnych zjawisk, związanych z procesem starzenia się społeczeństwa, kryzysu finansowego i gospodarczego, spowolnionego wzrostu gospodarczego, rosnącego deficytu budżetowego i długu publicznego, a także braku stabilności finansowej systemów emerytalnych czy niskiego poziomu zatrudnienia (wysokiego poziomu bezrobocia). Zjawiska te utrudniają systemom emerytalnym wypełnianie ich zobowiązań emerytalnych. Repartycyjne programy emerytalne są najbardziej narażone na spadek zatrudnienia i obniżanie wartości wpływających składek ubezpieczeniowych. Z kolei kapitałowe systemy emerytalne są wrażliwe na wahania wartości aktywów i zysków funduszy emerytalnych. Stąd wniosek, że zarówno repartycyjne, jak i kapitałowe systemy emerytalne napotykają na liczne bariery, spośród których najistotniejsze są problemy demograficzne.

Systemy emerytalne w krajach Unii Europejskiej pozostają nadal w kompetencji państw członkowskich, a na poziomie unijnym podlegają jedynie regułom otwartej koordynacji. Komisja Europejska zaleciła w 2014 r. modernizację krajowych systemów emerytalnych w 16 spośród 28 państw Unii Europejskiej, m.in. w kierunku [Borowczyk, 2014, s. 52]:

- podniesienia wieku emerytalnego i powiązania go ze średnią przewidywaną długością życia (zalecenia dla Austrii, Belgii, Chorwacji, Czech, Finlandii, Francji, Litwy, Luksemburga, Malty, Słowenii),

- ograniczenia dostępu do wcześniejszych emerytur i stworzenie rozwiązań zachęcających do późniejszego przechodzenia na emeryturę (zalecenia dla Austrii, Belgii, Bułgarii, Chorwacji, Czech, Finlandii, Litwy, Luksemburga, Niemiec), 
- zwiększenia możliwości dodatkowych ubezpieczeń emerytalnych (zalecenia dla Holandii, Litwy, Niemiec, Słowenii),

- ujednolicenia wieku emerytalnego kobiet i mężczyzn (zalecenia dla Austrii, Bułgarii, Chorwacji, Rumunii),

- przeglądu mechanizmu indeksacji (zalecenia dla Czech, Francji, Litwy),

- przeglądu systemów specjalnych (zalecenia dla Chorwacji, Francji, Polski),

- przeglądu systemu rent inwalidzkich (zalecenia dla Bułgarii, Chorwacji),

- podniesienia finansowej wydolności systemów emerytalnych (zalecenia dla Francji, Portugalii, Słowenii),

- zwiększenia możliwości zatrudnienia starszych pracowników (zalecenia dla Austrii, Czech, Finlandii, Francji, Holandii, Litwy, Luksemburga, Polski, Rumunii, Słowenii).

Zalecenia te wskazują na pożądane kierunki rozwoju systemów emerytalnych, które Unia Europejska zamierza konsekwentnie promować. Reformy emerytalne powinny zmierzać w kierunku zrównoważenia publicznych finansów emerytalnych, zachowania równowagi między okresem aktywności zawodowej i czasem spędzonym na emeryturze, a także sprzyjać tworzeniu uzupełniających prywatnych oszczędności emerytalnych (emerytury pracownicze i osobiste, ubezpieczenia na dożycie i inne rodzaje akumulacji aktywów, w tym odwrócona hipoteka).

Aby podstawy dla stabilnych i adekwatnych emerytur były solidne, należy przede wszystkim pobudzić wzrost gospodarczy w Europie i zwiększyć istotnie współczynniki zatrudnienia we wszystkich przedziałach wiekowych, co będzie zadaniem długookresowym i z pewnością niełatwym.

\section{Bibliografia}

1. Biała ksiegga. Plan na rzecz adekwatnych, bezpiecznych i stabilnych emerytur, Komisja Europejska, Bruksela, 16.02.2012 r.

2. Borowczyk E. (2014), Reformy włoskiego systemu emerytalnego, „Ubezpieczenia Społeczne. Teoria i Praktyka", nr 6 (123).

3. Council of the European Union, Joint report of the Social Protection Committee and the Economic Policy Committee on objectives and working methods in the area of pensions: applying the open method of coordination (10672/01 ECOFIN 198 SOC 272) z 23 listopada $2001 \mathrm{r}$.

4. Czepulis-Rutkowska Z. (2014), Przeobrażenia systemu emerytalnego w Wielkiej Brytanii, „Ubezpieczenia Społeczne. Teoria i Praktyka", nr 6 (123).

5. Economic and budgetary projections for the 27 EU Member States (2010-2060), The 2012 Ageing Report (2012), „European Economy”, nr 2, tabela A12, www.ec.europa.eu (dostęp: 6.10.2014).

6. EU Employment and Social Situation. Special Supplement on Demographic trends (2013), „Quarterly Review", March 2013. Trwanie życia w 2009 r. (2010), GUS, Warszawa.

8. Jurek Ł. (2011), Rekonstrukcja wieku emerytalnego w dobie demograficznego starzenia. Porównanie alternatywnych modeli rozwiazań, „Polityka Społeczna”, nr specjalny, „Problemy zabezpieczenia emerytalnego w Polsce i na świecie", cz. 1.

9. Key figures on Europe 2013 digest of the online Eurostat yearbook (2013), Eurostat Packetbooks, Luxemburg. 
10. Pensions at a Glance 2013: Retirement-Income Systems In OECD and G20 Coun, OECD 2013, www. oecd.org/pensions/pensionsataglance.htm (dostęp: 6.10.2014).

11. Pieńkowska-Kamieniecka S., Rutecka J. (2014), System emerytalny w Niemczech - analiza aktualnych tendencji na tle dotychczasowego procesu reformowania, „Ubezpieczenia Społeczne. Teoria i Praktyka", nr 6 (123).

12. Prognoza ludności na lata 2014-2050 (2014), Studia i Analizy Statystyczne, GUS, Warszawa.

13. Samborski A. (2011), Determinanty i kierunki zmian w systemach emerytalnych, „Polityka Społeczna”, nr specjalny, „Problemy zabezpieczenia emerytalnego w Polsce i na świecie”, cz. 1.

14. Szczur M. (2014), System emerytalny w Szwecji - przyktad innowacyjnego i stabilnego finansowo rozwiazania problemu zabezpieczenia dochodów na starość, „Ubezpieczenia Społeczne. Teoria i Praktyka", nr 6 (123).

15. Uścińska G. (2012), Wiek emerytalny w krajach Unii Europejskiej-obowiazujące rozwiazania i proponowane kierunki zmian, [w:] M. Żukowski, A. Malaka (red.), Wiek emerytalny, Polskie Stowarzyszenie Ubezpieczenia Społecznego, Kazimierz Dolny.

16. Ustawa z dnia 11 maja 2012 r. o zmianie ustawy o emeryturach i rentach z Funduszu Ubezpieczeń Społecznych oraz niektórych innych ustaw (Dz. U. z 2012 r., poz. 637).

17. Ustawa z dnia 13 października 1998 r. o systemie ubezpieczeń społecznych (tekst jednolity: Dz. U. z 2015 r., poz. 121).

18. World Population Prospects (2013), The 2012 Revision, Vol. II, Demographic Profiles, New York, www.esa.un.org (dostęp: 6.10.2014).

19. Zielona ksiega na rzecz adekwatnych, stabilnych i bezpiecznych systemów emerytalnych w Europie (2010), Bruksela.

20. Żukowski M. (2013), Dwie fale reform emerytalnych w krajach Europy Środkowo-Wschodniej 1998-2012, „Studia Oeconomica Posnaniensia”, vol. 1, nr 1 (250).

21. Żukowski M. (2007), Systemy emerytalne a aktywność zawodowa - w Polsce i innych krajach UE, [w:] J. Orczyk, M. Żukowski (red.), Aktywizujaca polityka społeczna, „Zeszyty Naukowe”, nr 89, Wydawnictwo Akademii Ekonomicznej w Poznaniu, Poznań.

\section{Demographic challenges for pension systems in the European Union}

The first part of the study characterizes the aging society in the EU countries, which leads, among others, to limiting the potential of the economic development and has negative effects from the point of view of public finance sustainability, and pension finances in particular. With falling incomes and rising pension expenditure, pension schemes in the EU find it increasingly difficult to guarantee adequate pensions. Due to this fact, at the European level, the co-operation in the area of pension security has been intensified. The remaining part of the paper presents a long-term plan of modernizing pension policy in the EU, which demonstrates the realization of the Method of Open Coordination (OMC) of pension schemes. 